\title{
The Serological Grouping of Three Strains of Streptococcus equinus
}

\author{
By R. FULLER AND L. G. M. NEWLAND \\ National Institute for Research in Dairying, University of Reading
}

(Received 11 October 1962)

\section{SUMMARY}

Group D antisera were prepared from three culture-collection strains of Streptococcus equinus. Reciprocal absorption tests showed that they were Group D streptococci.

\section{INTRODUCTION}

It is now well established that the streptococci are one of the predominant groups of organisms in the intestine of the pig (Raibaud \& Caulet, 1957; Fuller et al. 1960). Consequently the classification of streptococci from this source has recently attracted much attention and many different species have been described as predominating in the pig gut. The type of organism isolated from mixed populations is always in some measure dependent on the medium used. Since at least 30 different media have been used by various workers (see Raibaud et al. 1961) it is not surprising that conflicting claims have been made. However, apart from the variation which can be accounted for in this way, there is the problem of classifying organisms which bear resemblance to more than one species. The lactose non-fermenting streptococci isolated from the pig gut are an example of this latter group of organisms. In previous work (Fuller et al. 1960) numerous lactose non-fermenting Group D streptococci were isolated from pig faeces; because of their inability to ferment lactose or to hydrolyse starch they were classified as Streptococcus equinus, although other workers had classified similar strains as $S$. bovis (Raibaud \& Caulet, 1957). An objection to the classification of these lactose non-fermenting isolates as $S$. equinus was that they were of serological Group D, whereas no group specific antigen had so far been demonstrated for this species (Bergey's Manual, 1957). It was thus essential to know whether accepted strains of $S$. equinus were of serological Group D.

\section{METHODS}

Organisms examined. Streptococcus faecalis NCTC 775, S. faecalis var. liquefaciens (Elv. 2025) NCDo 588, S. faecalis var. zymogenes NCDo 586, S. faecium NCTC 7171, S. durans (98D) NCDo, 596, S. bovis (Pearl 11) NCDo 597, S. equinus ATCC 9812, NCDO 1090 and 1091. The three strains of Streptococcus equinus all conformed to the description given in Bergey's Manual (1957).

Media. For the preparation of vaccines and extracts organisms were grown for $24 \mathrm{hr}$. at $37^{\circ}$ in glucose Lemco broth (\%, w/v; Evan's peptone, 1; Lab. Lemco, 1 ; $\mathrm{NaCl}$ (Analar), 0.5; glucose, 1). 


\section{Serological methods}

Preparation of antisera. Antisera were prepared by using the three strains of Streptococcus equinus and the strain of $S$. bovis. Vaccines were prepared by the method of Shattock (1949). Saline suspensions of organisms were shaken in a tissue disintegrator (Mickle, 1948) for $90 \mathrm{~min}$. One ml. was injected into the ear vein of rabbits at 3- to 4-day intervals, fresh vaccine preparations being used for each injection. Eleven doses of $S$. equinus and nine of $S$. bovis were given. Test bleedings were made after six injections and antisera were tested by the ring precipitin test against $\mathrm{HCl}$ extracts of streptococci of serological groups $\mathrm{A}-\mathrm{O}$.

Antigen extracts. These were prepared by the method of Lancefield (1933) and when necessary were concentrated by precipitation with ethanol as described by Shattock (1949).

Absorption of antisera. The method of Shattock (1949) was used.

\section{RESULTS}

In preliminary tests after six injections, the three Streptococcus equinus antisera gave no precipitation with any of the extracts of groups $A$ to $O$ streptococci whilst the $S$. bovis antiserum reacted weakly with the group $D$ extract. At the end of the series of injections all four antisera reacted strongly with the extract prepared from $S$. faecalis 775, but when the sera were tested against extracts of the six different group D streptococci shown in Table 1 precipitation did not occur in all cases.

Table 1. Precipitin reactions of Streptococcus equinus and S. bovis group antisera with normal and concentrated extracts of group $D$ streptococci

\begin{tabular}{|c|c|c|c|c|c|c|c|c|c|c|c|c|}
\hline \multirow{3}{*}{ Antisera } & \multicolumn{12}{|c|}{ HCl-extracts of } \\
\hline & \multicolumn{2}{|c|}{ S. faecium } & \multicolumn{2}{|c|}{ S. faecalis } & \multicolumn{2}{|c|}{$\begin{array}{l}\text { S. faecalis } \\
\text { var. } \\
\text { liquefaciens }\end{array}$} & \multicolumn{2}{|c|}{$\begin{array}{c}\text { S. faecalis } \\
\text { var. } \\
\text { symogenes }\end{array}$} & \multicolumn{2}{|c|}{ S. durans } & \multicolumn{2}{|c|}{ S. bovis 597} \\
\hline & $\mathbf{N}$ & C & $\mathbf{N}$ & C & $\mathbf{N}$ & C & $\mathbf{N}$ & C & $\mathbf{N}$ & C & $\mathbf{N}$ & C \\
\hline & & & & & & & & & & & & \\
\hline 1090 & - & + & + & + & + & + & 一 & + & - & + & - & + \\
\hline 1091 & - & + & + & + & + & + & + & + & - & + & - & + \\
\hline 9812 & - & + & + & + & - & + & - & + & - & + & - & + \\
\hline S. bovis & & & & & & & & & & & & \\
\hline 597 & + & + & + & + & + & + & + & + & + & + & + & + \\
\hline
\end{tabular}

However, when the extracts were concentrated the four antisera reacted with all the group D extracts but were still negative to extracts of the other serological groups. Therefore, in subsequent tests concentrated extracts were used.

To confirm that Streptococcus equinus was group D, reciprocal absorption tests were made (Tables 2, 3). When the group $D$ antiserum prepared from $S$. bovis was absorbed with suspensions of $S$. equinus two absorptions were necessary to remove all the group $D$ antibodies. After this treatment the only precipitin reaction which occurred was the type reaction between the $S$. bovis antiserum and the homo- 
logous extract. One absorption was sufficient to remove the group D antibodies from the $S$. equinus antisera by using $S$. faecalis 775 . The only remaining reactions were those between homologous systems. There was no evidence from either of these tests of any shared type antigens, no cross precipitation occurring between the three strains of $S$. equinus or between these and $S$. bovis

Table 2. Absorption of group $D$ antiserum by Streptococcus equinus suspensions

\begin{tabular}{|c|c|c|c|c|c|}
\hline \multirow{3}{*}{$\begin{array}{l}\text { Antigen; } \\
\text { concentrated } \\
\text { extract from }\end{array}$} & \multicolumn{5}{|c|}{ Group D serum (S. bovis 597) } \\
\hline & \multirow[b]{2}{*}{ Unabsorbed } & \multicolumn{4}{|c|}{ Absorbed with } \\
\hline & & $\begin{array}{l}\text { S. equinus } \\
9812\end{array}$ & $\begin{array}{c}\text { S. equinus } \\
1090\end{array}$ & $\begin{array}{l}\text { S. equinus } \\
1091\end{array}$ & $\begin{array}{c}\text { S. bovis } \\
597\end{array}$ \\
\hline S. faecium & + & - & - & - & - \\
\hline$S$. faecalis & + & - & - & - & - \\
\hline var. liquefaciens & + & - & - & - & - \\
\hline var. zymogenes & + & - & - & - & - \\
\hline S. durans & + & - & - & - & - \\
\hline S. boois 597 & + & + & + & + & - \\
\hline S. equinus 9812 & + & - & - & - & - \\
\hline S. equinus 1090 & + & - & - & - & - \\
\hline S. equinus 1091 & + & - & - & - & - \\
\hline
\end{tabular}

Table 3. Absorption of Streptococcus equinus and S. bovis group $D$ antisera with $\mathrm{S}$. faecalis $\mathbf{7 7 5}$

\begin{tabular}{|c|c|c|c|c|c|c|c|c|}
\hline \multirow{3}{*}{$\begin{array}{l}\text { Antigen; concentrated } \\
\text { extract from }\end{array}$} & \multicolumn{8}{|c|}{ Antisera } \\
\hline & \multicolumn{2}{|c|}{ S. equinus 9812} & \multicolumn{2}{|c|}{ S. equinus 1090} & \multicolumn{2}{|c|}{ S. equinus 1091} & \multicolumn{2}{|c|}{ S. bovis 597} \\
\hline & Unabs. & Abs. & Unabs. & Abs. & Unabs. & Abs. & Unabs. & Abs. \\
\hline S. faecium & + & - & + & - & + & - & + & - \\
\hline S. faecalis & + & - & + & - & + & - & + & - \\
\hline var. liquefaciens & + & - & + & - & + & - & + & - \\
\hline var. zymogenes & + & - & + & - & + & - & + & - \\
\hline S. durans & + & - & + & - & + & - & + & - \\
\hline S. bovis 597 & + & - & + & - & + & - & + & + \\
\hline S. equinus 9812 & + & + & + & - & + & - & + & - \\
\hline S. equinus 1090 & + & - & + & + & + & - & + & - \\
\hline S. equinus 1091 & + & - & + & - & + & + & + & - \\
\hline
\end{tabular}

\section{DISCUSSION}

By using three culture collection strains of Streptococcus equinus we have prepared specific group $\mathrm{D}$ antisera thereby showing that $S$. equinus belongs to serological group D. It seems that the group $\mathrm{D}$ antigen is either serologically inaccessible or present in relatively small amounts as shown by the necessity to concentrate some extracts to get precipitation with Streptococcus equinus group antisera and the necessity to absorb twice with $S$. equinus suspensions to remove group $\mathbf{D}$ antibodies from a $S$. bovis group antiserum. This agrees with our previous findings (Fuller et al. 1960 ) that $S$. equinus strains isolated from pig faeces were difficult to group unless concentrated extracts were used. It may also explain past failures to detect a group specific antigen.

Since this work was completed Smith \& Shattock (1962) have reported on a 
collection of streptococci isolated from horse faeces and corresponding to the description of Streptococcus equinus (Andrewes \& Horder, 1906). These strains all produced the group $\mathbf{D}$ antigen and the preparation of a group $\mathbf{D}$ antiserum from one of these strains confirmed their opinion that $S$. equinus belongs to group $\mathrm{D}$.

Group D is at present comprised of Streptococcus faecalis and its two variants liquefaciens and zymogenes, $S$. durans, S. faecium and $S$. bovis. These organisms are all of intestinal origin and since $S$. equinus is the predominant streptococcus in horse faeces (Andrewes \& Horder, 1906) it is perhaps not surprising that, if it belongs to any of the existing groups, it should belong to group D. The similarity of the physiological characters of $S$. equinus and $S$. bovis (Sherman, 1937) supports the inclusion of $S$. equinus in group D. Seeley \& Dain (1960) stated that aside from the inability of $S$. equinus to ferment lactose, no significant differences exist in our present definitions and knowledge of the species. This close relationship to $S$. bovis coupled with a reluctance to place group $D$ organisms in a species for which no group antigen was known may have led to the classification of $S$. equinus isolates as $\boldsymbol{S}$. bovis. The acceptance of $S$. equinus as a member of serological group D removes the latter difficulty. More recently Smith \& Shattock (1962) have re-examined the relationship between the two species and suggest that when the physiological characters of each species are viewed as a whole, then a satisfactory separation can be made. We also believe that these two species can be separated on the basis of physiological tests and would propose that the species $S$. equinus be retained and in future included in group $D$.

We are indebted to Mr D. G. Smith and Dr P. M. Frances Shattock (Microbiology Department, University of Reading) for allowing us to quote from their paper before it was published.

\section{REFERENCES}

Andrewes, F. W. \& Horder, T. J. (1906). A study of the streptococci pathogenic for man. Lancet, ii, 708.

Bergey's Manual of Determinative Bacteriology (1957). 7th ed. Ed. by R. S. Breed, E. G. D. Murray \& N. R. Smith. London: Ballière, Tindall and Cox Ltd.

Fuller, R., Newland, L. G. M., Briggs, C. A. E., Braude, R. \& Mitchell, K. G. (1960). The normal intestinal flora of the pig. IV. The effect of dietary supplements of penicillin, chlortetracycline or copper sulphate on the faecal flora. J. appl. Bact. 23, 195.

LANCEFIELD, R. C. (1933). A serological differentiation of human and other groups of haemolytic streptococci. J. exp. Med. 57, 571.

MrckLe, H. (1948). Tissue disintegration J. Roy. Micros. Soc. 68, 10.

Raibaud, P. \& Caulet, M. (1957). Les streptocoques dominants dans le tube digestif du porc adulte. C.R. Acad. Sci., Paris, 244, 1291.

Raibaud, P., Caulet, M., Galpin, J. V. \& Mocquot, G. (1961). Studies on the bacterial flora of the alimentary tract of pigs. II. Streptococci. Selective enumeration and differentiation of the dominant group. J. appl. Bact. 24, 285.

Seeley, H. W. \& Dain, J. A. (1960). Starch hydrolysing streptococci. J. Bact. 79, 230.

Shatrock, P. M. F. (1949). The streptococci of group D; the serological grouping of Streptococcus bovis and observations on serologically refractory group D strains. J. gen. Microbiol. 3, 80.

Sherman, J. M. (1937). The streptococci. Bact. Rev. $1,3$.

Smith, D. G. \& Shatrock, P. M. F. (1962). The serological grouping of S. equinus. $J$. gen. Microbiol. (in the Press). 